\title{
THE CHARACTERISTICS OF NANOPARTICLE QUALITY OF SAND SEA CUCUMBER (Holothuria scabra) MEAT COLLAGEN WITH DIFFERENT STIRRING TIME.
}

\section{KARAKTERISTIK MUTU NANOPARTIKEL KOLAGEN DAGING TERIPANG PASIR (Holothuria scabra) DENGAN LAMA WAKTU PENGADUKAN BERBEDA.}

\author{
Syafrijal $^{1}$, Sumarto ${ }^{1}$, Dewita ${ }^{1}$ \\ ${ }^{1}$ Teknologi Hasil Perikanan Fakultas Perikanan dan Kelautan Universitas Riau, Jl. HR Soebrantas Km \\ 12,5 Simpang Baru, Panam - Pekanbaru, Indonesia 28293 Koresponden Author : \\ sumarto1976@yahoo.co.id
}

\begin{tabular}{|c|c|}
\hline I NFO A R T I K E L & A B S T R A C T \\
\hline $\begin{array}{l}\text { Diterima:12 September } 2018 \\
\text { Disetujui: } 28 \text { Oktober } 2018\end{array}$ & $\begin{array}{l}\text { This research was aimed to determine the characteristics of nanoparticle } \\
\text { auality of sand sea cucumber meat collagen (Holothuria scabra) with }\end{array}$ \\
\hline $\begin{array}{l}\text { Kata kunci: } \\
\text { Nanoparticle of } \\
\text { collagenSand sea cucumber } \\
\text { (Holoturia scabra) Stirring } \\
\text { time }\end{array}$ & $\begin{array}{l}\text { different stirring time. The method was carried out experimentally by } \\
\text { conducting an experiment on nanoparticles of meat sand sea cucumber } \\
\text { (Holothuria scabra) with different stirring i.e. } 1,2 \text { and } 3 \text { hours. The results } \\
\text { showed that on the fresh of meat sand sea cucumber has moisture, protein, } \\
\text { ash, fat, and carbohydrate content was } 78.94 \%, 79.67 \%, 6.74 \%, 4.82 \% \text {, and } \\
8.77 \% \text {, respectively. The nanoparticles of collagen produced showed that } \\
\text { different stirring time was affected by the quality characteristics of } \\
\text { nanoparticles of sea cucumber meat collagen. The best result was obtained } \\
\text { at } 3 \text { hours of stirring time which produced collagen nanoparticles with a } \\
\text { yield rate of } 14.33 \% \text {, moisture } 65.79 \% \text {, ash } 0.70 \% \text {, protein } 98.23 \% \text {, pH } 3.83 \\
\text { and particle size } 950 \text { nm. }\end{array}$ \\
\hline
\end{tabular}

\section{PENDAHULUAN}

Teripang merupakan sumberdaya alam dari laut yang saat ini menjadi sumber devisa negara, karena teripang menjadi komoditi ekspor non-migas, yang diekspor ke berbagai negara. Teripang juga sudah banyak dimanfaatkan untuk berbagai keperluan, terutama menjadi bahan pangan yang bergizi tinggi, dan menjadi sumber protein yang harganya cukup mahal serta menjadi bahan baku pada industri obat-obatan dan industri kosmetik (Riani, 2011).

Teripang secara ekonomis merupakan bahan makanan ekonomis yang memiliki kandungan nutrisi yang sangat tinggi. Teripang dalam kondisi kering pada umumnya mengandung protein $82 \%$, lemak 1,7\%, kadar air 8,9\%, kadar abu 8,6\%, dan karbohidrat 4,8\% (Martoyo et al., 2006). Tingginya nilai protein yang terkandung pada teripang sehingga sangat berp otensi untuk dijadikan kolagen. Sumber kolagen paling utama terdapat pada hewan. Hal ini dikarenakan hewan dapat mensintetis protein pada bagian-bagian selnya. Salah satu hewan yang mengandung kolagen adalah teripang pasir (Holothuria scabra). 
Kolagen merupakan protein utama penyusun struktur jaringan ikat golongan vertebrata dengan proporsi sekitar 30\% dari total protein tubuh manusia. Molekul kolagen berdiameter 1,5 $\mathrm{nm}$ dengan panjang $280 \mathrm{~nm}$ dan berat molekulnya 290.000 Dalton. Kandungan kolagen berupa tiga rantai polipeptida dengan lebih dari 1000 asam amino dimasing-masing rantainya (Asyiraf, 2011).

Pada umumnya kolagen sudah banyak dihasilkan baik dari daging, kulit maupun dari tulang, tetapi tidak dalam ukuran nanopartikel. Nanopartikel merupakan butiran atau partikel yang berukuran 10-1000 nm (Mohanraj dan Chen, 2006). Nanopartikel pertama kali dikembangkan sekitar tahun 1970 (Majeti dan Ravikumar, 2000).

Ukuran partikel merupakan faktor penting untuk menentukan efektivitas penggunaan kolagen dalam bidang biomedis dan kosmetik. Desai et al., (1997) menyatakan bahwa ukuran partikel mempengaruhi penyerapan seluler. Oleh karena itu diperlukan teknologi pengecilan ukuran melalui nanoteknologi yang dapat meningkatkan efektivitas dan penyerapan kolagen. Salah satu cara pembuatan nanopartikel kolagen dapat dibuat menggunakan metode yang sederhana dan mudah diterapkan, yaitu dengan lama waktu pengadukan (stirrer) yang bertujuan gar memperoleh ukuran nanopartikel kolagen dengan ukuran yang paling terkecil.

Wulandari (2016), telah berhasil membuat nanopartikel kolagen dengan ukuran terkecil yaitu $253.49 \mathrm{~nm}$ dengan sizing lama waktu pengadukan selama 1 jam. Sedangkan Mahardika (2013), mendapatkan ukuran nanopartikel kolagen rata-rata sebesar 146,71 nm dengan waktu pengadukan (stirrer) selama 2 jam. Berdasarkan uraian tersebut maka penulis tertarik untuk melakukan penelitian tentang karakteristik mutu nanopartikel kolagen daging teripang pasir (Holothuria scabra) dengan lama waktu pengadukan berbeda. Hasil penelitian ini dapat mendukung pengembangan lebih lanjut terkait aplikasi kolagen dari biota perairan pada produk pangan maupun nonpangan.

\section{METODE PENELITIAN}

\section{Bahan dan alat}

Bahan utama yang digunakan dalam penelitian ini adalah teripang pasir (Holothuria scabra) yang diperoleh dari perairan Batam Provinsi Kepulauan Riau. Bahan yang digunakan untuk ekstraksi kolagen meliputi akuades, natrium hidrosida $(\mathrm{NaOH}) 35 \%$, asam klorida $(\mathrm{HCl}) 6 \mathrm{~N}$ dan bahan kimia lainnya untuk analisis proksimat, sedangkan bahan untuk pembuatan nanopartikel kolagen adalah etanol $96 \%$.

Alat-alat yang digunakan antara lain pisau, nampan, talenan, blender, timbangan digital, lemari pendingin, gelas beaker, erlenmeyer, gelas ukur, cawan, timbangan, sentrifuse, oven, tanur, labu khjedhal, pH meter, magnetic stirrer dan PSA (Vasco-Particle Size Analyzer 2010).

\section{Metode Penelitian}

Metode penelitian yang digunakan adalah metode eksperimen yaitu melakukan percobaan terhadap nanopartikel daging teripang pasir (Holothuria scabra) menggunakan lama waktu pengadukan berbeda. Rancangan percobaan yang digunakan adalah Rancangan Acak Lengkap (RAL) non-faktorial yang terdiri dari 3 taraf perlakuan dengan 3 kali ulangan. Perlakuan yang diberikan adalah dengan lama waktu pengadukan berbeda yaitu NKT 1 (pengadukan 1 jam), NKT 2 (pengadukan 2 jam) dan NKT 3 (pengadukan 3 jam). Masing-masing perlakuan diulangi 3 kali sehingga didapat 9 kali percobaan. Adapun parameter yang diuji adalah kadar air, abu, protein, pH, rendemen, dan PSA (Paricle Size Analyzer). berikut:

Model matematis yang diajukan menurut rancangan Gaspersz (1991), adalah sebagai

$$
\begin{aligned}
& \text { Yij } \quad=\mu+\pi \mathrm{i}+\varepsilon \mathrm{ij} \\
& \text { Keterangan : } \\
& \text { Yij } \quad=\text { Variabel yang diukur I = } 1 \text { (banyak perlakuan) }
\end{aligned}
$$


$\mathrm{J} \quad=1,2,3$ (banyak ulangan)

$\mathrm{M} \quad=$ Nilai tengah umum (rata- rata)

$\pi \mathrm{i} \quad=$ Pengaruh perlakuan ke- $\mathrm{i}$

eij = Pengaruh galat ke-j yang memperoleh perlakuan ke-i.

\section{Prosedur Penelitian}

\section{Tahap Penyiangan Teripang Pasir}

Pada tahap awal teripang segar dibersihkan, dicuci dan dipisahkan dari bagian yang tidak diinginkan. Selanjutnya dilakukan pemisahan daging teripang dengan bagian tubuh lainnya (kulit, jeroan dan gonad, serta air dan kotoran). Hasil penyiangan diperoleh bagian daging, kulit dan isi perut (jeroan dan gonad). Daging teripang yang diperoleh digunakan untuk bahan penelitian dan dilakukan perhitungan proporsi daging $(\%)$ teripang pasir.

\section{Tahap Ekstraksi Kolagen}

Daging teripang dipotong menjadi bagian yang lebih kecil, kemudian daging dihaluskan dengan cara diblender untuk dijadikan daging lumat. Tujuan daging teripang dihaluskan atau dilumatkan untuk mempermudah pada saat ekstraksi dan mempermudah pada saat pengadukan.

Sampel daging lumat teripang kemudian ditimbang sebanyak $100 \mathrm{~g}$ bahan dan disuspensikan dalam aquades dengan rasio bahan aquades (1:2 b/v) dan diatur pH-nya dengan cara penambahan $\mathrm{NaOH} 35 \%$ secara bertahap menggunakan pipet tetes sambil diaduk menggunakan magnetic stirrer sampai mencapai $\mathrm{pH} 11$. Selanjutnya dipanaskan pada suhu $40^{\circ} \mathrm{C}$ selama 30 menit sambil diaduk menggunakan magnetic stirer dan selanjutnya di sentrifuse pada kecepatan $5000 \mathrm{rpm}$ selama 30 menit (sentrifuse 1). Supernatan (larutan kolagen) dipisahkan, dan diatur pH-nya menjadi 4-5 (titik isoelektrik kolagen) dengan cara penambahan $\mathrm{HCl} 6 \mathrm{~N}$ secara bertahap menggunakan pipet tetes sambil diaduk menggunakan magnetic stirrer.

\section{Tahap Pembuatan Nanopartikel Kolagen}

Larutan kolagen yang diperoleh dilakukan proses sizing (pengecilan ukuran) dengan sistem magnetic stirrer dengan perlakuan lama waktu pengadukan berbeda yaitu selama 1 jam, 2 jam dan 3 jam dengan suhu $40^{\circ} \mathrm{C}$. Larutan kolagen ditambahkan dengan etanol $96 \%$ sebagai agen desolvasi dengan rasio (1:1, v/v) sambil diaduk dengan magnetic stirrer dengan kecepatan 500 rpm. Tujuan penambahan etanol untuk mengurangi jumlah air yang dapat diikat oleh molekul kolagen dan meningkatkan reaksi hidrofobik dengan terbentuknya ikatan hidrogen molekul kolagen. Selanjutnya disentrifuse pada kecepatan $5000 \mathrm{rpm}$, selama 30 menit. Endapan yang diperoleh kemudian dikeringkan dengan menggunakan oven dengan suhu $35^{\circ} \mathrm{C}$ sehingga diperoleh sampel dalam bentuk nanopartikel kolagen daging teripang pasir.

\section{HASIL DAN PEMBAHASAN}

\section{Proporsi bagian tubuh teripang pasir}

Tahapan pemisahan bagian tubuh teripang pasir diikuti dengan proses pembersihan dengan air bersih, selanjutnya dilakukan pemisahan bagian daging, kulit, jeroan dan kotoran sisa makanan. Berdasarkan hasil pemisahan daging, kulit, gonad dan jeroan teripang pasir pada Tabel 1. daging teripang yang didapat dengan berat $2735 \mathrm{~g}$, kulit dengan berat $2180 \mathrm{~g}$, gonad $595 \mathrm{~g}$ dan jeroan $470 \mathrm{~g}$ dari sekitar $5980 \mathrm{~g}$ teripang pasir segar. Daging teripang yang di dapat pada penelitian ini terbilang cukup banyak. Hal ini menunjukkan bahwa daging dan kulit dari teripang pasir dapat dibedakan sehingga dapat untuk dipisahkan.

\section{Kandungan Kimia Daging Teripang Pasir}

Hasil analisis proksimat teripang pasir segar dapat dilihat pada Tabel 2.

Hasil analisis komposisi kimia menunjukkan bahwa kadar air yang terkandung dalam daging teripang pasir mencapai $78,94 \%$ (bb). Hasil penelitian teripang pasir sebelumnya menunjukkan kadar air mencapai 87,33\% (bb) (Karnila, 2012). Kadar air yang dihasilkan pada penelitian 
berbeda diduga karena pada proses pemotongan daging teripang masih ada kulit teripang yang tertempel dibagian dagingnya.

Kadar protein teripang pasir yaitu $79,67 \%$ (bk). Hasil penelitian ini didapatkan kadar protein yang lebih tinggi dari hasil teripang pasir sebelumnya menunjukkan kadar protein $72,93 \%$ (bk) (Karnila, 2012). Kondisi ini menunjukkan bahwa teripang memiliki nilai gizi yang baik sebagai bahan pangan. Protein di dalam tubuh dapat berupa cadangan makanan, zat pembangun dan zat pengatur. Protein sebagai zat pengatur merupakan bahan pembentuk jaringan-jaringan baru yang selalu terjadi dalam tubuh (Karnila, 2012).

Kadar abu daging teripang pasir adalah 6,74\% (bk). Hasil ini menunjukkan kadar abu yang sedikit rendah dibandingkan hasil penelitian teripang pasir sebelumnya yakni kadar abu mencapai 16,5\% (bk) (Karnila, 2012). Hal ini menunjukkan kadar abu daging teripang pasir tidak terlalu tinggi, disebabkan daging teripang sudah dipisahkan dari kulit tubuh teripang. Kulit teripang merupakan dinding tubuh yang terdiri dari kutikula yang merupakan lapisan pelindung yang tertutup kapur dan adanya duri-duri yang merupakan butir-butir kapur mikroskopis yang tersebar pada lapisan epidermis (Fetcher, 1969).

Kadar lemak teripang pasir adalah 4,82\% (bk). Hal ini disebabkan bagian daging atau tubuh terdiri dari jaringan otot serta osikel yang merupakan tempat menyimpan lemak serta adanya pembuluh darah yang kemungkinan besar mengandung lemak yang akan disebarkan ke seluruh bagian tubuh (Nurjanah, 2008).

\section{Nanopartikel Kolagen Daging Teripang Pasir}

\section{Kadar Air}

Hasil uji kadar air nanopartikel kolagen daging teripang pasir yang dihasilkan dari perlakuan lama waktu pengadukan yang berbeda dapat dilihat pada Tabel 3 .

Ket: Angka-angka yang diikuti oleh huruf yang berbeda pada kolom yang sama berarti berbeda nyata menurut uji lanjut BNJ.

Tabel 3 hasil analisis variansi menunjukkan bahwa nilai kadar air nanopartikel kolagen daging teripang pasir dengan lama waktu pengadukan berbeda berpengaruh nyata, dimana $\mathrm{F}_{\text {hitung }}$ $(6,1401)>\mathrm{F}_{\text {tabel }} 0,05(5,14)$ pada tingkat kepercayaan $95 \%$, maka $\mathrm{H}_{0}$ ditolak.

Setelah dilakukan uji lanjut BNJ, nilai kadar air nanopartikel kolagen daging teripang pasir pada perlakuan NKT 1 berbeda nyata dengan nilai pada perlakuan NKT 3, serta perlakuan NKT 2 tidak berbeda nyata.

Lama waktu pengadukan yang berbeda memberikan perbedaan jumlah kadar air yang signifikan dari masing-masing nanopartikel kolagen. Semakin lama waktu pengadukan semakin berkurang kadar air yang di hasilkan. Hal ini dapat dilihat rata-rata analisis kadar air nanopartikel kolagen daging teripang pasir yang semakin turun nilainya dari NKT 1 dengan nilai $69,79 \%$, NKT 2 dengan nilai 67,58\%, dan NKT 3 dengan nilai 65,79\%. Nanopartikel kolagen yang dihasilkan dari beberapa perlakuan tersebut memiliki kadar air yang tinggi dibandingkan dengan standar mutu air kolagen yang telah ditetapkan yaitu $\leq 12 \%$ (SNI, 2004).

\section{Kadar Abu}

Hasil uji kadar abu nanopartikel kolagen daging teripang pasir yang dihasilkan dari pemberian perlakuan lama waktu pengadukan yang berbeda dapat dilihat pada Tabel 4 .

Berdasarkan Tabel 4, hasil analisis variansi menunjukkan bahwa nilai kadar abu nanopartikel kolagen daging teripang pasir yang dihasilkan dari perlakuan lama waktu pengadukan yang berbeda tidak ada pengaruh pada kadar abu, dimana $F_{\text {hitung }}(3,5930)<\mathrm{F}_{\text {tabel }}$ $0,05(5,14)$ pada tingkat kepercayaan $95 \%$, maka $\mathrm{H}_{0}$ diterima sehingga tidak dilakukan uji lanjut.

Pada Tabel 4 menunjukkan rata-rata hasil analisis kadar abu nanopartikel kolagen daging teripang pasir yang semakin turun nilainya dari NKT 1 dengan nilai $0,83 \%$, NKT 2 dengan nilai $0,76 \%$, dan NKT 3 dengan nilai $0,70 \%$. Kadar abu yang dihasilkan oleh nanopartikel kolagen 
daging teripang pasir dengan lama waktu pengadukan berbeda tersebut memiliki kadar abu yang rendah sehingga memenuhi standar mutu kolagen yang telah di tetapkan yaitu $\leq 1 \%$ (SNI, 2004).

\section{Kadar Protein}

Hasil nilai rata-rata kadar protein nanopartikel kolagen daging teripang pasir dengan lama waktu pengadukan yang berbeda dapat dilihat pada tabel 5 .

Berdasarkan Tabel 5 hasil analisis variansi menunjukkan bahwa nilai kadar protein nanopartikel kolagen daging teripang pasir yang dihasilkan dari perlakuan lama waktu pengadukan yang berbeda tidak berpengaruh pada protein $F_{\text {hitung }}(3,4446)<\mathrm{F}_{\text {tabel }}(5,14)$ pada tingkat kepercayaan 95\% maka hipotesis diterima. Sehingga tidak perlu dilakukan uji lanjut.

Pada Tabel 5 menunjukkan rata-rata hasil analisis kadar protein nanopartikel kolagen daging teripang pasir NKT 1 dengan nilai 97,57\%, NKT 2 dengan nilai 98,05\%, dan NKT 3 dengan nilai $98,23 \%$. Kadar protein yang dihasilkan oleh nanopartikel kolagen daging teripang pasir lebih tinggi dibandingkan dengan kadar protein nanopartikel kolagen dari kulit ikan pari yaitu 86,18\% (bk) (Nur'aenah, 2013). Berdasarkan hasil penelitian ini kadar protein nanopartikel kolagen yang dihasilkan memiliki kadar protein yang tinggi sehingga memenuhi standar mutu kolagen yang telah ditetapkan yaitu 80-88\% (SNI, 2004).

\section{Nilai pH}

Hasil nilai rata-rata $\mathrm{pH}$ nanopartikel kolagen daging teripang pasir dengan lama waktu pengadukan yang berbeda.

Berdasarkan Tabel 6 hasil analisis variansi menunjukkan bahwa nilai nilai $\mathrm{pH}$ nanopartikel kolagen daging teripang pasir dengan lama waktu pengadukan berbeda menyatakan bahwa $\mathrm{F}_{\text {hitung }}$ $(0.1666)<\mathrm{F}_{\text {tabel }}(5,14)$ pada tingkat kepercayaan $95 \%$ maka hipotesis diterima. Sehingga tidak perlu dilakukan uji lanjut.

Pada Tabel 6 dapat dilihat bahwa nilai $\mathrm{pH}$ pada nanopartikel kolagen daging teripang pasir berturut-turut adalah 3,87 dan 3,83. Nilai $\mathrm{pH}$ ini lebih rendah dibandingkan dengan nanopartikel kolagen teripang gamma dari penelitian Alhana (2015) dan Yusida (2016) yaitu 7,61 dan 6,85. Nilai pH kolagen berbeda ini disebabkan oleh jumlah konsentrasi asam yang digunakan pada proses hidrolisis. Penggunaan konsentrasi asam tinggi menyebabkan kolagen yang dihasilkan bersifat asam. Selain itu, nilai $\mathrm{pH}$ rendah juga disebabkan oleh proses netralisasi kurang sempurna (Wulandari, 2016). Nilai pH nanopartikel kolagen pada penelitian ini lebih rendah sesuai dengan standar kolagen yang ditetapkan oleh BSN (2014), bahwa standar nilai pH kolagen berkisar antara 6,5-8. Peng et al., (2004) mengatakan bahwa nilai pH pada beberapa merk kolagen berkisar antara 3,8-4,7.

\section{Karakteristik Nanopartikel Kolagen}

\section{Rendemen}

Hasil nilai rendemen nanopartikel kolagen daging teripang pasir yang dihasilkan dari perlakuan lama pengadukan yang berbeda dapat dilihat pada Tabel 7 .

Pada Tabel 7 hasil analisis variansi menunjukkan bahwa nilai rendemen nanopartikel kolagen daging teripang pasir dengan lama waktu pengadukan berbeda berpengaruh nyata, dimana $\mathrm{F}_{\text {hitung }}(6,3333)>\mathrm{F}_{\text {tabel }} 0,05(5,14)$ pada tingkat kepercayaan $95 \%$, maka $\mathrm{H}_{0}$ ditolak, sehingga di lakukan uji lanjut BNJ.

Hasil uji BNJ menyatakan perlakuan NKT 1 berbeda nyata dengan perlakuan NKT 3, sedangkan perlakuan NKT 2 tidak berbeda nyata. Hal ini menyatakan rendemen nanopartikel kolagen daging teripang pasir di pengaruhi oleh lama waktu pengadukan yang berbeda. Pada proses lama waktu pengadukan, rendemen nanopartikel kolagen dengan rendemen tertinggi dihasilkan pada waktu 3 jam dengan persentase rendemen sebesar $14,33 \%$, diikuti dengan waktu 2 jam sebesar 13,33\% dan waktu 1 jam sebesar 12,67\%. Rendemen nanopartikel kolagen ini lebih tinggi dibandingkan dari rendemen nanopartikel kolagen yang dihasilkan dari penelitian nur'aenah (2013) yaitu sebesar 9,64\% (bb). 


\section{Uji PSA (Particle Size Analyzer)}

Hasil rata-rata ukuran nanopartikel kolagen daging teripang pasir dapat dilihat pada Tabel 8 .

Perlakuan lama waktu pengadukan berbeda pembuatan nanopartikel kolagen mengalami pengecilan ukuran yang signifikan dari ukuran awal kolagen dengan ukuran $2368 \mathrm{~nm}$, menjadi NKT 1 sebesar $1468 \mathrm{~nm}$, NKT 2 sebesar $1271 \mathrm{~nm}$, dan NKT 3 sebesar $950 \mathrm{~nm}$. Ukuran nanopartikel kolagen teripang pasir ini lebih besar dibandingkan dari ukuran nanopartikel kolagen teripang gamma yang dihasilkan dari penelitian Yusida (2016) dan Alhana (2015) yaitu sebesar $603,9 \mathrm{~nm}$ dan $158,88 \mathrm{~nm}$. Besarnya ukuran nanopartikel kolagen pada penelitian ini yaitu disebabkan oleh hasil optimasi lama waktu pengadukan yang belum sempurna untuk memecah partikel

menjadi partikel berukuran nano, selain itu kecepatan pengadukan juga berpengaruh terhadap ukuran partikel kolagen.

Berdasarkan data rata-rata ukuran nanopartikel kolagen hasil penelitian, NKT 1 dengan lama pengadukan selama 1 jam memiliki rata-rata ukuran $1468 \mathrm{~nm}$, NKT 2 dengan lama waktu pengadukan selama 2 jam memiliki rata-rata ukuran $1271 \mathrm{~nm}$ dan NKT 3 dengan lama waktu pengadukan selama 3 jam memiliki rata-rata ukuran $950 \mathrm{~nm}$.

Hasil optimasi lama waktu pengadukan menunjukkan bahwa seiring dengan meningkatnya lama pengadukan maka ukuran partikel yang dihasilkan semakin kecil, hal ini dikarenakan semakin banyak partikel terpecah menjadi partikel berukuran nano, selain itu peningkatan lama pengadukan akan memperbesar intensitas molekul pelarut untuk bersentuhan dengan kolagen sehingga ukuran partikel yang dihasilkan semakin kecil (Chang, 2005).

Maka dapat disimpulkan bahwa ukuran rata-rata ukuran nanopartikel kolagen daging teripang pasir yang dihasilkan yaitu NKT 1 dan NKT 2 belum termasuk dalam kategori nanopartikel sesuai dengan referensi yang diperoleh karena memiliki ukuran yang masih terlalu besar, sedangkan NKT 3 telah sesuai dengan referensi yang menyatakan bahwa nanopartikel didefinisikan sebagai partikel yang terisolasi yang memiliki ukuran sekitar 10-1000 nm (Mohanraj dan Chen, 2006).

Tabel 1. Berat dan persentase hasil pemisahan bagian tubuh teripang pasir segar.

\begin{tabular}{|c|c|c|c|}
\hline No & Bagian Teripang & Berat (g) & Persentase $(\%)$ \\
\hline 1 & Daging & 2735 & 45,73 \\
\hline 2 & Kulit & 2180 & 36,45 \\
\hline 3 & Gonad & 595 & 9,94 \\
\hline 4 & Jeroan & 470 & 7,85 \\
\hline Total & & 5980 & 100 \\
\hline
\end{tabular}

Kandungan $\quad$ Persentase (\%)

Tabel 2. Hasil analisis proksimat teripang pasir segar 


\begin{tabular}{lcc}
\hline Kadar air & 78,94 (bb) \\
Kadar abu & $6,74 \quad$ (bk) \\
Kadar protein & 79,67 (bk) \\
Kadar lemak & 4,82 (bk) \\
Kadar karbohidrat* & $8,77 \quad$ (bk)
\end{tabular}

Tabel 3. Nilai rata-rata kadar air (\%) nanopartikel kolagen daging teripang pasir dengan lama waktu pengadukan yang berbeda.

\begin{tabular}{lcccl}
\hline \multirow{2}{*}{ Perlakuan } & \multicolumn{3}{c}{ Ulangan $(\%)$} & Rata-rata \\
\cline { 2 - 4 } & 1 & 2 & 3 & \\
\hline NKT 1 & 69,50 & 68,41 & 71,44 & $69,79^{\mathrm{b}}$ \\
NKT 2 & 67,44 & 66,16 & 69,16 & $67,58^{\text {ab }}$ \\
NKT 3 & 67,05 & 65,41 & 68,90 & $65,79^{\mathrm{a}}$
\end{tabular}

Ket: Angka-angka yang diikuti oleh huruf yang berbeda pada kolom yang sama berarti berbeda nyata menurut uji lanjut BNJ

Tabel 4. Nilai rata-rata kadar abu (\%) nanopartikel kolagen daging teripang pasir dengan lamawaktu pengadukan yang berbeda.

\begin{tabular}{|c|c|c|c|c|}
\hline \multirow{2}{*}{ Perlakuan } & \multicolumn{3}{|c|}{ Ulangan (\%bk) } & \multirow{2}{*}{ Rata-rata } \\
\hline & 1 & 2 & 3 & \\
\hline \multirow{2}{*}{$\begin{array}{l}\text { PKTT1 } \\
\text { NKT } 2\end{array}$} & 0,84 & Ulangan (\%bk) & 0,82 & \multirow{2}{*}{$\begin{array}{l}\text { Rata-rata } \\
0,76\end{array}$} \\
\hline & 6,87 & 0,72 & 0,723 & \\
\hline NKT 31 & $9794 B 0$ & 09715,77 & $0,6797,52$ & $0,97,57$ \\
\hline NKT 2 & 97,74 & 98,59 & 97,81 & 98,05 \\
\hline NKT 3 & 98,10 & 98,12 & 98,49 & 98,23 \\
\hline
\end{tabular}

Tabel 5. Nilai rata-rata kadar protein $(\%)$ nanopartikel kolagen daging teripang pasir dengan lama waktu pengadukan yang berbeda.

Tabel 6. Nilai rata-rata $\mathrm{pH}$ nanopartikel kolagen daging teripang pasir dengan lama waktu pengadukan yang berbeda.

\begin{tabular}{lcccc}
\hline \multirow{2}{*}{ Perlakuan } & \multicolumn{3}{c}{ Ulangan } & \multirow{2}{*}{ Rata-rata } \\
\cline { 2 - 4 } & 1 & 2 & 3 & \\
\hline NKT 1 & 4,0 & 3,8 & 3,8 & 3,87 \\
NKT 2 & 3,9 & 3,8 & 3,9 & 3,87
\end{tabular}


Tabel 7. Nilai rata-rata rendemen (\%) nanopartikel kolagen daging teripang pasir dengan lama waktu pengadukan yang berbeda.

\begin{tabular}{lcccc}
\hline \multirow{2}{*}{ Perlakuan } & \multicolumn{3}{c}{ Ulangan (\%bb) } & \multirow{2}{*}{ Rata-rata } \\
\cline { 2 - 4 } & 1 & 2 & 3 & \\
\hline NKT 1 & 13 & 13 & 12 & $12,67^{\mathrm{a}}$ \\
NKT 2 & 14 & 13 & 13 & $13,33^{\mathrm{ab}}$ \\
NKT 3 & 14 & 15 & 14 & $14,33^{\mathrm{b}}$ \\
\hline
\end{tabular}

Ket: Angka-angka yang diikuti oleh huruf yang berbeda pada kolom yang sama berarti berbeda nyata menurut uji lanjut BNJ.

Tabel 8. Rata-rata ukuran nanopartikel kolagen daging teripang pasir

\begin{tabular}{ll}
\hline Perlakuan & Rerata ukuran $(\mathrm{nm})$ \\
\hline KT & 2368 \\
NKT 1 & 1468 \\
NKT 2 & 1271 \\
NKT 3 & 950 \\
\hline Ket: KT & =Kolagen teripang (kontrol) \\
NKT 1 & $=$ Nanopartikel kolagen teripang $\quad$ (lama pengadukan 1 jam) \\
NKT 2 & $=$ Nanopartikel kolagen teripang (lama pengadukan 2 jam) \\
NKT 3 & $=$ Nanopartikel kolagen teripang (lama pengadukan 3 jam)
\end{tabular}

Tabel 9. Perbandingan karakteristik mutu nanopartikel kolagen dengan lama waktu pengadukan berbeda dengan standar mutu kolagen.

\begin{tabular}{lllcc}
\hline Parameter & \multicolumn{3}{c}{ Nanopartikel kolagen } \\
\cline { 2 - 5 } & \multicolumn{1}{c}{ NKT 1 } & NKT 2 & NKT 3 & Standar mutu kolagen \\
\hline Kadar air & $69,79 \%$ & $67,5 \%$ & $65,7 \%$ & $<12 \% *$ \\
Kadar abu & $0,83 \%$ & $0,76 \%$ & $0,70 \%$ & $<1 \% *$ \\
Kadar protein & 97,57 & 98,05 & $98,23 \%$ & $80-88 \% *$ \\
& $\%$ & $\%$ & & $6,5-8^{*}$ \\
Ph & 3,87 & 3,87 & 3,83 & $10-1000 \mathrm{~nm}^{* *}$ \\
Uji PSA & 1468 & 1271 & 950 &
\end{tabular}

Keterangan : $\quad * S N I 8076,2014 * *$ Monharaj dan Chen, 2006 


\section{KESIMPULAN}

Hasil penelitian menunjukan bahwa karakteristik mutu nanopartikel kolagen daging teripang pasir dengan lama waktu pengadukan berbeda berpengaruh nyata terhadap nilai rendemen dan kadar air, sedangkan nilai kadar abu, protein dan nilai $\mathrm{pH}$ tidak berpengaruh nyata.

Nanopartikel kolagen daging teripang pasir dengan perlakuan pengadukan selama 3 jam (NKT 3) merupakan perlakuan yang terbaik yaitu memiliki rendemen 14,33\%, kadar air 65,79\% (bb) , kadar abu 0,70\%, kadar protein 98,23\% (bk) dan nilai $\mathrm{pH} 3,83$.

\section{DAFTAR PUSTAKA}

[BSN] Badan Standardisasi Nasional. 2014. Kolagen kasar dari sisik ikan-Syarat mutu dan pengolahan: SNI 8076-2014. Jakarta (ID) : Badan Standardisasi Nasional.

Alhana. 2015. Ekstraksi dan karakterisasi kolagen dan nanokolagen dari daging teripang gamma (Stichopus variegatus) [tesis]. Bogor (ID) : Institut Pertanian Bogor.

Asyiraf, N. 2011. Extraction of Collagen From Fish Waste and Determination of Its Physicochemical Characteristic, Final Project, Degree of Bachelor of Science (Hons.) Food Science and Technology, Faculty of Applied Sciences, Selangor: Universiti Teknologi MARA.

Chang R. 2005. Kimia Dasar: Konsep-Konsep Inti Jilid 2. Jakarta: Erlangga.

Desai MP, Labhasetwar V, Walter E, Levy RJ, Amidon GL. 1997. The mechanism of uptake of biodegradable microparticles in $\mathrm{CaC}$ o-2 cells is size dependent. Pharmaceutical Research. 14:1568-1573.

Fechter H. 1969. The Sea Cucumber. Grzimek B, editor. Grzimek's Animal Life Encyclopedia. New York: Van Nostrand Reinhold Company.

Gaspers, V. 1991. Metode Perancangan Percobaan. CV. ARMICO. Bandung.

Karnila R, Astawan M, Sukarno, Wresdiyati T. 2011. Analisis kandungan nutrisi daging dan tepung teripang pasir (Holothuria scabra j) segar. Berkala Perikanan Terubuk. Vol. 39. No.2. ISSN $0126-4265$.

Karnila R. 2012. Daya hipoglikemik hidrolisat, konsentrat, danisolat protein teripang pasir (Holothuria scabra) pada tikus percobaan. [Disertasi]. Sekolah Pascasarjana. Institut Pertanian Bogor. Bogor.

Mahardika, S. 2013. Isolasi dan karakterisasi kolagen nanopartikel dari kulit ikan cucut bambu (Chiloscyllium punctatum) [Skripsi]. Bogor (ID): Institut Pertanian Bogor.

Majeti N, Ravikumar V. 2000. Nano and microparticle as controlled drug delivery devices. Journal of Pharmacy and Pharmaceutical Sciences 3(2):234-258.

Martoyo J, Aji N, Winanto T.J. 2006. Budidaya Teripang. Jakarta (ID): Penebar Swadaya.

Monharaj VJ and Y Chen. 2006. Nanoparticles-A Review. Tropical Journal of Pharmaceutical Research 5(1): 561-573.

Nur'aenah N. 2013. Ekstraksi dan karakterisasi kolagen dan nanopartikel kolagen dari kulit ikan pari (pastinachus solocirostris) sebagai bahan baku kosmetik [Tesis]. Sekolah Pascasarjana, Institut Pertanian Bogor. 
Nurjanah S. 2008. Identifikasi steroid teripang pasir (Holothuria scabra) dan bioassay produk teripang sebagai sumber aprodisiaka alami dalam upaya peningkatan nilai tambah teripang. [Disertasi]. Bogor: Sekolah Pascasarjana, Institut Pertanian Bogor.

Peng Y, Glattauer V, Werkmeister JA, Ramshaw JAM. 2004. Evaluation for collagen products for cosmetic application. Journal of Cosmestic Science 55(4):327341.doi:10.1111/j.14672494.2004.00245_2.x.

Riani, E. 2011. Pengelolaan sumberdaya teripang pasir (Holothuria scabra) berdasarkan biologi reproduksinya dalam rangka mendukung perikanan berkelanjutan. Departemen Manajemen Sumberdaya Perairan Fakultas Perikanan dan Ilmu Kelautan Institut Pertanian Bogor. JPSL Vol. (1) 2 : 114-119 Desember 2011.

Wulandari. 2016. Karakterisasi fisikokimia kolagen yang diisolasi dengan metode hidroekstraksi dan stabilisasi nanokolagen kulit ikan gabus (Channa striata) [Tesis]. Bogor (ID): Institut Pertanian Bogor.

Yusida, A. 2016. Formulasi sediaan krim berbasis nanokolagen teripang gamma (Stichopus variegatus). [Skripsi]. Bogor (ID): Institut Pertanian Bogor. 